\title{
HUBUNGAN TINGKAT PENGETAHUAN IBU TENTANG EFEK SAMPING KONTRASEPSI SUNTIK DENGAN KEIKUTSERTAAN MENJADI AKSEPTOR KB SUNTIK DI BPS NY. ARIFIN SURABAYA
}

Eny Astuti *Mience Dappa** enyastutiserang@gmail.com, STIKes William Booth Surabaya, Prodi D-III Kebidanan Stikes William Booth,Jalan. Cimanuk No.20 Surabaya 60241

\begin{abstract}
ABSTRAK
Kontrasepsi merupakan suatu cara atau metode yang bertujuan untuk mencegah pembuahan sehingga tidak terjadi kehamilan. Kontrasepsi suntik adalah salah satu metode yang paling diminati. Namun banyak sekali akseptor KB suntik yang belum memahami tentang efek samping kontrasepsi suntik sehingga tujuan penelitian adalah untuk mengetahui hubungan antara tingkat pengetahuan ibu tentang efek samping kontrasepsi suntik dengan menjadi akseptor KB suntik. Desain yang digunakan pada penelitian adalah "korelasi". Pemilihan sample dilakukan dengan teknik consecutive sampling, pengumpulan data menggunakan alat ukur kuesioner, sampel diambil dari responden yang bersedia (akseptor KB baru dan Ibu yang kooperatif) Berdasarkan hasil penelitian diatas disimpulkan sebagian besar pengetahuan ibu tentang efek samping kontrasepsi suntik adalah kurang sebanyak 20 responden $(50 \%)$ dan sebanyak 28 responden $(70 \%)$ tetap ikut menjadi akseptor KB suntik. Data diolah menggunakan uji statistik chi square dengan hasil $\rho=0.763$ yang berarti $\mathrm{H}_{0}$ diterima yaitu tidak ada hubungan antara pengetahuan ibu tentang efek samping kontrasepsi suntik dengan menjadi akseptor KB suntik. Peneliti berharap petugas kesehatan lebih memotivasi para ibu yang belum menggunakan KB agar memberikan informasi betapa pentingnya KB untuk menekan jumlah kelahiran, angka kemtian ibu dan kesakitan.
\end{abstract}

Kata Kunci: Pengetahuan, Akseptor Keluarga Berencana, Kontrasepsi Suntik

\begin{abstract}
ABSTRAC
Contraception is a way or method that aims to prevent conception so pregnancy does not occur. One of the most desirable method of contraception is a contraceptive injection. But a lot of injection acceptors who do not understand about the side effects of injectable contraceptives so that the purpose of the study was to determine the relationship between the mother's level of knowledge about side effects of injectable contraceptives to become acceptors syringe. The design used in the study was a "correlation". Selection of the sample was done by using consecutive sampling, data collection using questionnaires measuring devices, samples were taken from all respondent acceptors new, cooperative and willing mothers studied. A large sample of 40 respondents. Based on the above results concluded most of the mother knowledge about side effects of CICs is less by 20 respondents $(50 \%)$ and as many as 28 respondents $(70 \%)$ still come into acceptor injections. The data is processed using chi square statistical test with results $\rho=0.763$ which means that $\mathrm{H}_{0}$ is accepted that there is no relationship between maternal knowledge about side effects of injectable contraceptives to become acceptors syringe. Health workers are expected to further motivate the mothers who do not use birth control in order to provide information about the importance of family planning to reduce maternal morbidity and mortality and the number of births.
\end{abstract}

Keywords: Knowledge, Family Planning Acceptors, Injectable Contraception 


\section{PENDAHULUAN}

Kualitas Sumber Daya Manusia dan jumlah kelahiran 5.000.000 pertahun masih menjadi masalah di Indonesia. Dalam bidang kependudukan, pemerintah sudah menegaskan paradigm KB sejak GBHN 1999. Keluarga kecil bahagia dan sejahtera masih menjadi visi program KB dengan slogan dua anak cukup dan menjadi keluarga berkualitas tahun 2015 (Saroha Pinem, 2009). KB suntik menjadi salah satu pilihan kontrasepsi efektif karena efektif, aman, sederhana dan murah (Muchtar, 2002). Usia ibu, jumlah keluarga, status pekerjaan ibu, tingkat pendidikan ibu, tingkat pengetahuan ibu tentang alat kontrasepsi suntik serta dukungan keluarga khususnya suami menjadi faktor yang menyebabkan ibu memilih menggunakan alat kontrasepsi suntik (Hartanto, 2004). Menurut Notoatmojo 2012, domain yang sangat penting untuk menentukan tindakan dan motivasi seseorang adalah pengetahuan. Akan tetapi banyak ibu yang tidak memahami kontrasepsi hormonal. Kontrasepsi hormonal sama seperti suntik sangat efektif dan tingkat reversibilitasnya tinggi dan memiliki daya kerja yang lama. Akan tetapi, ada efek samping menggunakan kontrasepsi suntik seperti amenorea (30\%), spoting (bercak darah) dan menoragia, seperti halnya dengan kontrasepsi hormonal lainnya dan dijumpai pula keluhan mual, sakit kepala $(<1-17 \%)$ (pusing), perubahan berat badan (7-9\%) (Hartanto, 2004). Calon akseptor kontrasepsi suntik tidak semunya memahami efek samping tersebut. Berdasarkan pengalaman peneliti di BPS Ny. Arifin, masih banyak akseptor $\mathrm{KB}$ suntik yang mengeluh dengan kenaikan berat badan yang semakin bertambah, siklus haid yang tidak lancar, dan penurunan libido. Setelah peneliti bertanya apakah ibu-ibu tersebut sudah mengetahui bahwa kenaikan berat badan, siklus haid yang tidak lancar, maupun penurunan libido tersebut tersebut merupakan bagian dari efek samping kontrasepsi suntik, mereka mengatakan mereka tidak tahu bahwa itu merupakan bagian dari efek samping kontrasepsi suntik. Peneliti juga bertanya kepada beberapa calon akseptor yang mau menjadi akseptor KB suntik mengapa mereka mau menjadi akseptor KB suntik dan apakah mereka sudah tahu tentang efek sampingnya, ada yang mengatakan karena penggunaannya tidak setiap hari dan tidak ada efek sampingnya, ada yang mengatakan karena anjuran teman dan efek sampingnya hanya kenaikan berat badan, ada juga yang mengatakan karena paling mudah dan efek sampingnya hanya gangguan haid.
Menurut Dinkes (2009), sampai saat ini di Indonesia cakupan peserta KB aktif (Contraceptive Prevalence Rate/CPR mencapai $61,4 \%$ (SDKI, 2007). Sebanyak 8.500.247 orang menjadi peserta kontrasepsi aktif di indonesia dengan persentase suntik $48,56 \%$, pil $26,60 \%$, implan 9,23\%, IUD 7,75\%, kondom 6,09\%, MOW $1,52 \%$, MOP $0,25 \%$. Di Jawa Timur tahun 2011, sebanyak 6.150 .153 orang total menjadi peserta KB aktif. Dari total tersebut peserta KB aktif, pengguna KB suntik sebanyak $48,2 \%$, pil $21,01 \%$, IUD atau spiral $14 \%$, implan $8,5 \%$, medis operatif wanita $5 \%$, kondom $1,5 \%$, dan pengguna medis operatif pria $0,4 \%$. Sedangkan di Surabaya pada tahun 2013, akseptor KB naik menjadi 61.599 jiwa. Rinciannya, metode suntik sebanyak 31.721 orang, pil sebanyak 17.083 orang, IUD 5.252, kondom 3.292 orang, MOW (metode operasi wanita) 2.659 orang, implan 1.292 orang, dan MOP (metode operasi pria) 302 orang. Di BPS Ny. Arifin pada bulan Desember 2015 sebanyak 72 peserta yang menggunakan alat kontrasepsi dengan persentase 44 peserta KB suntik $(61,11 \%), 8$ peserta pil $(11,11 \%), 9$ peserta implant $(12,50 \%), 11$ peserta IUD $(15,28 \%)$, MOW dan MOP (0\%), kondom (0\%). Berdasarkan studi pendahuluan yang dilakukan, data dari wawancara di BPS Ny. Arifin, Wonorejo IV Surabaya ada 5 akseptor KB suntik yang ditanya oleh peneliti apakah ibu tersebut sudah mendengar informasi tentang efek samping kontrasepsi suntik, 3 orang mengatakan tidak tahu, 1 orang mengatakan hanya mengetahui kenaikan berat badan, dan 1 orang lagi mengatakan haid tidak teratur sebagai efek samping kontrasepsi suntik. Peneliti juga bertanya kepada 5 calon akseptor KB suntik mengapa mereka mau menjadi akseptor $\mathrm{KB}$ suntik dan apakah mereka sudah tahu tentang efek sampingnya, 2 orang mengatakan karena penggunaannya tidak setiap hari dan tidak ada efek sampingnya, 1 orang mengatakan karena anjuran teman dan efek sampingnya hanya kenaikan berat badan, 2 orang lagi mengatakan karena paling mudah dan efek sampingnya hanya gangguan haid.

Berdasarkan hasil penelitian di beberapa negara berkembang, akseptor KB mengalami kecemasan dan ketakutan terhadap efek samping yang ditimbulkan (Saifuddin, 2006). Banyak dari mereka yang tidak memahami efek samping dari kontrasepsi suntik tersebut sehingga diperlukan pemberian pengetahuan. Salah satu efek samping dari penggunaan kontrasepsi suntik adalah kenaikan berat badan berlebihan. 
Menjadi gemuk merupakan mimpi buruk bagi sebagian orang terutama bagi mereka yang sangat memperhatikan penampilan. Hal ini juga bisa mempengaruhi kepercayaan diri dan berkaitan dengan karir yang bersangkutan. Apabila tidak ditangani dengan tepat dapat menimbulkan beberapa penyakit dan gangguan kesehatan yang dapat terjadi akibat berat badan yang berlebih seperti Diabetes Melitus, masalah pada jantung, persendian, hipertensi dan gangguan hormonal (Purwati, 2005).

Untuk mengatasi ketidaktahuan ibu tentang efek samping kontrasepsi suntik sebaiknya petugas kesehatan menyebarkan leaflet, membuat banner, dan memberikan penyuluhan tentang efek samping dari penyuntikan kontrasepsi suntik, serta konseling tentang efek samping bagi ibu-ibu akseptor baru kontrasepsi suntik. Dengan memberikan informasi tersebut ibu tidak akan kuatir dan cemas akan efek samping yang timbul setelah penyuntikan kontrasepsi suntik. Berdasarkan uraian di atas, maka peneliti tertarik untuk meneliti Hubungan Tingkat Pengetahuan Ibu Tentang Efek Samping Kontrasepsi Suntik dengan Menjadi Akseptor KB Suntik di BPS Ny. Arifin, Wonorejo IV/33 Surabaya.

\section{BAHAN DAN METODE}

Metode yang digunakan dalam penelitian ini adalah korelasional. Metode ini digunakan untuk menjelaskan hubungan antar variable. Pendekatan yang digunakan adalah cross sectional. Pada penelitian ini peneliti ingin mengetahui hubungan antara variabel independen yaitu tingkat pengetahuan ibu tentang efek samping kontrasepsi suntik dan variabel dependen yaitu keikutsertaan menjadi akseptor KB suntik. Populasi dalam penelitian ini adalah Semua ibu Calon akseptor baru KB di BPS Ny. Arifin ada 40 orang. Dalam penelitian ini peneliti mengambil sampel - ibu akseptor baru kontrasepsi yang memenuhi kriteria di BPS Ny. Arifin. Teknik total sampling digunakan dalam pengambilan sampel pada penelitian ini. Alat ukur yang dipakai dengan menggunakan Kuesioner tentang pengetahuan ibu tentang efeksamping kontrasepsi suntik dan Keikutsertaan ibu KB menjadi akseptor KB Suntik.

\section{HASIL}

Hasil pengumpulan data tentang Hubungan Tingkat Pengetahuan Ibu Tentang Efek Samping Kontrasepsi Suntik Dengan Keikutsertaan Menjadi Akseptor KB Suntik di BPS Ny. Arifin
Wonorejo IV/33 Surabaya", adalah sebagai berikut.

1. Karakteristik Responden berdasarkan Umur. Tabe1 1. Karakteristik Responden Berdasarkan Umur

\begin{tabular}{cccc}
\hline No & Umur & F & \% \\
\hline 1 & $<25$ tahun & 12 & $30 \%$ \\
2 & $26-34$ tahun & 19 & $48 \%$ \\
3 & $>35$ tahun & 9 & $23 \%$ \\
\hline & Total & 40 & $100 \%$ \\
\hline
\end{tabular}

Berdasarakan Tabe1 1 di atas menunjukkan bahwa terbanyak responden berumur 26-44 tahun, yaitu sebanyak 19 responden (48\%).

2. Karakteristik Responden berdasarkan Pendidikan Terakhir.

Tabe1 2. Karakteristik Pendidikan Terakhir Responden

\begin{tabular}{cccc}
\hline No & Pendidikan & F & \% \\
\hline 1 & SD & 3 & $8 \%$ \\
2 & SMP & 12 & $30 \%$ \\
3 & SMA & 17 & $43 \%$ \\
4 & PT & 8 & $20 \%$ \\
\hline & Total & 40 & $100 \%$ \\
\hline
\end{tabular}

Berdasarkan tabel 2 dapat diketahui bahwa terbanyak responden dengan pendidikan terakhir SMA, yaitu sebanyak 17 responden $(43 \%)$.

3. Karakteristik Responden berdasarkan Pekerjaan.

Tabel 3 Karakteristik Pekerjaan Responden

\begin{tabular}{lccc}
\hline No & Pekerjaan & F & \% \\
\hline 1 & PNS & 4 & $10 \%$ \\
2 & Swasta & 18 & $45 \%$ \\
3 & IRT & 18 & $45 \%$ \\
\hline & Total & 40 & $100 \%$ \\
\hline
\end{tabular}

Berdasarkan tabel 3 menunjukkan bahwa Ibu Rumah Tangga dan Swasta merupakan responden terbanyak dengan jumlah masing masing 18 atau $45 \%$.

4. Karakteristik Responden berdasarkan Pendapatan.

Tabe1 4. Karakteristik Responden Berdasarkan Pendapatan

\begin{tabular}{cccc}
\hline No & Pendapatan & F & \% \\
\hline 1 & Rp. $<1.000 .000$ & 5 & $13 \%$ \\
2 & Rp. $1 \mathrm{Jt}-$ Rp. $2 \mathrm{Jt}$ & 22 & $55 \%$ \\
3 & Rp. $>2.000 .000$ & 13 & $33 \%$ \\
\hline & Total & & $100 \%$ \\
\hline
\end{tabular}

Berdasarkan tabel 4 dapat diketahui bahwa sebagian besar responden memiliki 
pendapatan sebanyak Rp. 1.000 .000 - Rp. 2.000 .000 yaitu 22 responden $(55 \%)$.

5. Karakteristik Responden berdasarkan Tingkat pengetahuan.

Tabe1 5. Karakteristik Responden Berdasarkan Tingkat Pengetahuan

\begin{tabular}{cccc}
\hline No & Pengetahuan & F & \% \\
\hline 1 & Baik & 7 & $18 \%$ \\
2 & Cukup & 13 & $33 \%$ \\
3 & Kurang & 20 & $50 \%$ \\
\hline & Total & 40 & $100 \%$ \\
\hline
\end{tabular}

Tabel 5 menunjukkan bahwa sebanyak 20 responden (50) berpengetahuan kurang.

6. Karakteristik Responden berdasarkan Keikutsertaan menjadi Akseptor KB Suntik.

Tabe1 6 Karakteristik Berdasarkan Keikutsertaan menjadi Aseptor KB suntik.

\begin{tabular}{cccc}
\hline NO & Menjadi Akseptor KB Suntik & F & \% \\
\hline 1 & Ikut & 28 & $70 \%$ \\
2 & Tidak Ikut & 12 & $30 \%$ \\
\hline & Total & 40 & $100 \%$ \\
\hline
\end{tabular}

Berdasarkan tabel 6 dapat diketahui bahwa sebagian besar responden tetap memilih untuk ikut menjadi akseptor KB suntik, yaitu 28 responden $(70 \%)$.

7. Hubungan Pengetahuan Ibu Tentang Efek Samping Kontrasepsi Suntik Dengan Keikutsertaan Menjadi Akseptor KB Suntik

Tabel 7. Tabulasi Silang Hubungan Tingkat Pengetahuan Ibu Tentang Efek Samping Kontrasepsi Suntik Dengan Keiutsertaan Menjadi Akseptor KB Suntik di BPS Ny. Arifin.

\begin{tabular}{cccccc}
\hline \multirow{2}{*}{$\begin{array}{c}\text { Tingkat } \\
\text { Penget }\end{array}$} & \multicolumn{4}{c}{ Keikutsertaan Menjadi } & \\
& \multicolumn{4}{c}{ Akseptor KB Suntik } & Tot \\
& Ik & $\%$ & $\begin{array}{c}\text { Tidak } \\
\text { Ikut }\end{array}$ & $\%$ & al \\
& ut & & Ikut & \\
\hline Baik & 5 & $71 \%$ & 2 & $29 \%$ & 7 \\
Cukup & 11 & $79 \%$ & 3 & $21 \%$ & 14 \\
Kurang & 12 & $63 \%$ & 7 & $37 \%$ & 19 \\
Total & 28 & & 12 & & 40 \\
\hline
\end{tabular}

Hasil Uji Statistik Chi Square $\rho=0.763$

Berdasarkan tabel 7 menunjukkan bahwa pengetahuan baik menunjukkan lebih banyak yang ikut menjadi akseptor KB suntik yaitu sebanyak $71 \%$, pengetahuan cukup lebih banyak yang ikut menjadi akseptor KB suntik yaitu sebanyak 79\%, dan pengetahuan kurang juga menunjukkan lebih banyak yang ikut menjadi akseptor KB suntik yaitu sebanyak $63 \%$. Hasil iji chi square menunjukkan nilai $\mathrm{p}=0,673$. Hal ini berarti tidak ada hubungan antara tingkat pengetahuan ibu tentang efek samping kontrasepsi suntik dengan menjadi akseptor KB suntik.

\section{PEMBAHASAN}

Pada pembahasan akan diuraikan hasil penelitian mengenai Hubungan Tingkat Pengetahuan Ibu Tentang Efek Samping Kontrasepsi Suntik Dengan Menjadi Akseptor KB suntik di BPS Ny. Arifin Wonorejo IV/33 Surabaya.

1. Tingkat Pengetahuan Tentang Efek Samping Kontrasepsi Suntik

Berdasarkan tabel 4.4 menunjukkan dari hasil penelitian didapatkan bahwa terbanyak dari 40 responden memiliki pengetahuan yang kurang yaitu sebanyak 20 orang $(50 \%)$ responden. Faktor pendidikan merupakan salah satu yang mempengaruhi. Menurut Mubarak tahun 2007, makin tinggi pendidikan makin mudah akses informasi yang didapatkan dan ada kaitannya dengan pengetahuan yang didapat. Menurut Notoatmodjo (1998), pengetahuan dipengaruhi oleh pendidikan salah satunya dimana pendidikan mempengaruhi daya tangkap seseorang dalam penerimaan informasi yang baru. Tingkat pendidikan responden yang berpengetahuan rendah menyebabkan tidak mampu menyerap informasi yang telah diterima meskipun informasi tersebut mudah didapat. Namun pada kenyataan yang ditemukan saat penelitian, sebagian besar responden memiliki tingkat pendidikan SMA tetapi memiliki pengetahuan yang kurang tentang efek samping kontrasepsi suntik. Ini dikarenakan kurangnya informasi tentang efek samping kontrasepsi suntik yang didapat dari bidan dan sebagian responden memiliki pekerjaan sebagai Ibu Rumah Tangga sehingga banyak responden yang kurang mendapat informasi tentang efek samping kontrasepsi suntik.

Pekerjaan juga dapat mempengaruhi tingkat pengetahuan seseorang. Berdasarkan tabel 4.3 menunjukkan bahwa sebagian besar responden bekerja sebagai Swasta, yaitu 18 responden (45\%) dan Ibu Rumah Tangga sebanyak 18 responden (45\%). Pengalaman dan pengetahuan yang baik juga dapat diperoleh dari pekerjaan baik itu secara langsung maupun tidak. Sebagian besar 
responden bekerja sebagai Ibu Rumah Tangga sehingga ibu-ibu tersebut cenderung lebih banyak meluangkan waktu untuk mengurus anak dan rumah tangga yang menyebabkan ibu-ibu kurang mencari informasi tentang efek samping kontrasepsi suntik.

2. Menjadi Akseptor KB Suntik

Berdasarkan tabel 4.5 menunjukkan bahwa dari 40 responden yang sudah diteliti sebagian besar tetap memilih untuk menjadi akseptor KB suntik, yaitu 28 orang $(70 \%)$. Akseptor adalah orang yang menjalani program keluarga berencana (KBBI, 2001 dalam Setiawan dan Saryono 2010). Menurut Saifuddin (2006), banyak akseptor yang lebih memilih menjadi akseptor KB suntik karena memiliki keuntungan diantaranya sangat efektif, resiko terhadap kesehatan kecil, tidak berpengaruh pada hubungan suami istri, tidak diperlukan pemeriksaan dalam waktu yang lama, efek samping sangat kecil, klien tidak perlu menyimpan obat suntik, dan pada kontrasepsi suntik 3 bulan tidak mempengaruhi ASI. Berdasarkan tabel 4.1 menunjukkan bahwa responden terbanyak berumur 26-34 tahun dengan jumlah 19 responden (48\%). Kematangan seseorang ditentukan oleh factor umur baik dalam berpikir maupun bekerja (Notoatmodjo, 1998), dimana pada umur 25-34 tahun sudah tergolong dewasa sehingga dapat membuat keputusan sendiri dalam memilih dan ikut menjadi akseptor KB suntik. Menurut Mubarak (2007), minat menjadikan seseorang untuk mencoba dan menekuni suatu hal dan pada akhirnya diperoleh pengetahuan yang lebih mendalam. Meskipun pengetahuan responden rendah tetapi karena minat mereka akan mencoba untuk ikut menjadi akseptor KB suntik.

3. Hubungan Tingkat Pengetahuan Ibu Tentang Efek Samping Kontrasepsi Suntik Dengan Menjadi Akseptor KB Suntik

Berdasarkan tabel 4.6 menunjukkan bahwa paling banyak respoden yang tetap memilih untuk ikut menjadi akseptor KB suntik dengan tingkat pengetahuan yang kurang, yaitu sebanyak 12 responden (43\%). Pada hasil uji statistik uji square diperoleh $\rho=0.763$ sehingga $\rho>0,05$ maka $\mathrm{H}_{0}$ diterima yang artinya tidak ada hubungan yang bermakna antara pengetahuan ibu dengan menjadi akseptor KB suntik. Hasil penelitian menunjukkan bahwa tidak ada hubungan bermakna antara pengetahuan ibu tentang efek samping kontrasepsi subtik dengan menjadi akseptor KB. Pengambilan keputusan dipengaruhi oleh rasional yang didapatkan dari pengetahuan, informasi yang didapatkan dan pemahaman akan situasi (George Terry). Sebagian besar responden memiliki pengetahuan kurang, tetapi mereka tetap mengambil keputusan untuk menjadi akseptor KB suntik karena berdasarkan pengalaman orang lain, ada juga yang hanya ikut-ikutan dan ada juga yang memilih kontrasepsi suntik dengan alasan tidak dipakai setiap hari. Jadi, seseorang memilih sesuatu tidak selamanya didasari oleh pengetahuan tetapi juga karena pengaruh dari orang-orang sekitar.

\section{SIMPULAN}

Kesimpulan yang dapat diambil adalah sebagai berikut: tingkat pengetahuan responden tentang efek samping kontrasepsi suntik sebagian besar berpengetahuan kurang, responden terbanyak tetap memilih untuk ikut menjadi akseptor KB suntik, Tidak ada hubungan antara tingkat pengetahuan ibu dengan menjadi akseptor KB suntik.

\section{SARAN}

Saran yang diberikan oleh peneliti adalah: bagi peneliti selanjutnya, diharapkan penelitian ini dapat menjadi acuan dan gambaran bagi penelitian selanjutnya dalam mengembangkan penelitian dengan judul "Faktor-faktor Yang Mempengaruhi Ibu Menjadi Akseptor KB Suntik", bagi Bidan di BPS Ny. Arifin Surabaya, diharapkan tetap memberikan konseling kepada calon akseptor, khususnya tentang keuntungan, kerugian dan efek samping penggunaan kontrasepsi suntik, bagi STIKES William Booth Surabaya, dapat menambah wawasan dan pengetahuan dan ketrampilan mahasiswa terutama dalam melakukan penyuluhan, sehingga pada saat mahasiswa terjun ke lapangan sudah menguasai materi cara melakukan penyuluhan yang benar yaitu dengan cara berkomunikasi yang benar dan dapat dimengerti oleh masyarakat sehingga masyarakat dapat menerima segala informasi dan mematuhi setiap saran yang diberikan oleh petugas kesehatan.

\section{DAFTAR PUSTAKA}

Arikunto, Suharsimi. 2010. Prosedur Penelitian: Suatu Pendekatan Praktek. Jakarta: Rineka Cipta 
Eva ellya sibagariang, dkfk. 2010. Kesehatan reproduksi wanita. Jakarta: cv. Trans info media

BKKBN. 2009. Kesehatan Reproduksi. Jakarta

Friedman. 2002. Keperawatan Keluarga Teori dan Praktik. Jakarta: ECG

Hartanto, Hanafi.1994. Keluarga Berencana dan Kontrasepsi. Jakarta: Pustaka Sinar Harapan

Hartanto, 2004. Keluarga Berencana dan Kontrasepsi. Jakarta: Pustaka dan Sinar Harapan

Hidayat, A. Aziz Alimul. 2007. Riset Keperawatan dan Teknik Penulisan Ilmiah Edisi 2. Jakarta: Salemba Medika

.2010. Metode Penelitian Keperawatan dan Teknik Analisis Data. Jakarta: Salemba Medika

Mubarak, Wahit Iqbal dkk. 2007. Promosi Kesehatan: Sebuah Pengantar Proses Belajar Mengajar Dalam Pendidikan Ed.1. Yogyakarta: Graha Ilmu

Mochtar, 2002. Sinopsis Kebidanan. Jakarta. EGC

Notoatmodjo, Soekidjo. 2003. Pendidikan dan Perilaku Kesehatan. Jakarta: PT Rhineka Cipta

2007. Kesehatan Masyarakat Ilmu dan Seni. Jakarta: Salemba Medika

\section{.2010. Ilmu Perilaku Kesehatan. Jakarta: PT Rhineka Cipta \\ 2007. Promosi Kesehatan dan Perilaku Kesehatan. Jakarta: PT Rhineka Cipta}

Nazir, Mohammad. 2011. Metode Penelitian. Bogor: Ghalia Indonesia

Nursalam, 2008. Konsep dan Penerapan Metodologi Penelitian Ilmu Keperawatan Pedoman Skripsi, Tesis, dan Instrumen Penelitian Keperawatan. Jakarta: Salemba Medika

Pinem, Saroha. 2009. Kesehatan Reproduksi dan Kontrasepsi. Jakarta: TIM

Saifuddin, 2003. Buku Panduan Praktis Pelayanan Kontrasepsi. Jakarta: YBP
Setiadi. 2007. Konsep dan Penulisan Riset Keperawatan. Yogyakarta: Graha Ilmu

Sugiyono. 2007. Statistik Untuk Penelitian. Bandung: CV Alfabeta

. 2011. Metode Penelitian Kuantitatif, Kualitatif, dan R\&D. Bandung: CV Alfabeta

Sulistyawati, Ari. Pelayanan Keluarga Berencana. Jakarta: Salemba Medika, 2011 